\title{
Equalizing Quality: The Challenge of Globalization
}

\author{
Siti Ina Savira \\ Department of Psychology, Universitas Negeri Surabaya
}

\begin{abstract}
This essay is aimed to discuss one contemporary issue in relation to Indonesia. The issue being raised here is globalization and its effect on how Indonesia perceived itself as a nation. This paper will argue my position in viewing globalization as a force that seems to manifest in a blind movement that rapidly change our way of life at the cost of social justice. One example I emphasize on my paper is the impact in educational paradigm, which can be seen from some educational discourses.
\end{abstract}

Keywords: Globalization, social justice, education

\begin{abstract}
Abstrak: Tulisan ini bertujuan untuk membahas salah satu isu kontemporer terkait dengan Indonesia, yaitu fenomena globalisasi dan efeknya terhadap bagaimana orang Indonesia mempersepsi diri sebagai sebuah bangsa. Tulisan ini memandang globalisasi sebagai kekuatan yang bergerak dengan senyap yang dengan cepat mengubah cara hidup kita dengan mengorbankan keadilan sosial. Salah satu kasus yang ditekankan dalam tulisan ini adalah dampaknya terhadap paradigma pendidikan di Indonesia yang dapat ditilik melalui beberapa wacana pendidikan yang ada.
\end{abstract}

Kata kunci: Globalisasi, keadilan sosial, pendidikan

Globalization can be defined many ways by many different people. However, some agreements can be drawn from those definitions. It is one of common agreement that globalization would refer to 'integration' ("Globalization, Growth, and Poverty: Building an inclusive world economy," 2002), 'universalization' (Gandin, 2011), or 'diffusion' ("ILO Declaration on Social Justice for a Fair Globalization," 2008) of people and commodities around the world (Gandin, 2011; "Globalization, Growth, and Poverty: Building an inclusive world economy," 2002; "ILO Declaration on Social Justice for a Fair Globalization," 2008). Other similarity in the definition of globalization lies in the emphasis of global competition or 'international competitiveness'(Bloom, 2006; Sakhiyya, 2011). The latter aspect of globalization would be the focus of discussion in this paper. But first, some general issues regarding globalizetion will be briefly discussed. The discussion surrounding globalization is yet to settle, but no one will argue that it is not happening.

The discourse around globalization is often reflected by the segregation between the dominant and the less dominant, the 'over-developed' and the 'less-developed', or between the 'north' and the 'south' countries as positioned in the world map (Gandin, 2011). Some of those terminologies were contested and criticised, but the fact that countries in the world are somehow divided into categories that reflect their domination in the world remains. And like any other dominant movement, the counter-dominant would emerge as an alternative position.

Korespondensi tentang artikel ini dapat dialamatkan kepada SIti Ina Savira melalui email:inasavira@unesa.ac.id. 
Despite the World Bank claims that countries that are either rejected globalization or that are now being ignored by globalization, do not seem to be better off (Gindin, 2002) and some statistical evident that shows that globalization does reduce poverty and helps the involving country to increase its economic growth are offered ("Globalization, Growth, and Poverty: Building an inclusive world economy," 2002), a lot of discussions toward globalization remain sceptical. The antiglobalization against globalization, counterhegemony against hegemony (Gandin, 2011), or even socialism against capitalism (Gindin, 2002) or 'neo-liberalism' (Hursh \& Henderson, 2011) that often is being associated to globalization, has come forward in attempt to raise awareness toward 'hidden agenda' of globalization. More radical discussion would also refer to globalization as another or subtler form of colonization of the 'westerns' or 'US domination' or even 'US imperialism' (Gindin, 2002). In this paper, some literatures using those different terms will be used to make a broader description of globalization.

\section{Discussion}

It is somewhat an irony that the countries that are rejecting or are being ignored by globalization are not doing any better is also because of the global movement of globalization. For instance, globalization as an outcome of capitalism and neoliberal policies (Hursh \& Henderson, 2011) would want to expect less regulation in market-trade and business that will allow rapid movement of goods and materials (Gindin, 2002; Hursh \& Henderson, 2011). It is reasonable to expect that the countries that are not in agreement to that policy would have some trading and business problems with other countries that endorse such regulation, which inevitably affecting their economic growth. The global movement does not seem to leave any choice for not being affected by it.

The world's segregation is also reinforced with massive international assessment projects that rank countries to see where they are positioned in relation to the world. Some examples are the projects conducted by the United Nations Development Program's Human Development Index. Indonesia for instance, was ranked in 111 out of 182 nations surveyed world-wide in 2007, while The World Competitiveness Year Book in the same year placed Indonesia 53 out of 55 nations (as cited in Sakhiyya, 2011). In 2011, Indonesia's Human Development Index was ranked 124 out of 187 countries surveyed ("Human Development Report," 2011). Another example is the PISA studies conducted by OECD (Organization for Economic Co-operation and Development), where Indonesia is in the 'lowest tier in each of the four items of the studies - mathematics, reading, science, and problem solving (OECD, 2003, as cited in Kustulasari, 2009). Such practice has a huge impact in how a nation perceived oneself in relation to the world and how global competition is manifested.

Furthermore, the current curriculum, Curriculum 2013, was based on an 'empirical data' on PISA (Program for International Student Assessment) and TIMSS (Trends in International Mathematics and Science Study), which both show that Indonesia is significantly low on understanding complex information, theory, analysis and problem solving, and technical skill, following procedure and problem solving, and conducting investigation (Kemendikbud, 2012). The following part of the document claims that it is important to shift the orientation of the curriculum from content-oriented to ability-oriented which is essential for citizens to be able to actively participate to 
build the country (Kemen-dikbud, 2012; writers' translation).

Therefore, the way that globalization is impacting the less dominant countries is usually shown by the change in power relation ("Globalization, Growth, and Poverty: Building an inclusive world economy," 2002). The less dominant countries would tend to take the 'importer' position, which means that countries like Indonesia would import the 'standard' used by the more dominant countries (Sakhiyya, 2011) in order to increase its position in the world rank.

Some problems can be drawn from those issues. First is, whether the adoption of these standards reflects national aspirations and promotes equality and second, whether pursuing global competition is at cost to social justice. The answer to both questions can be seen from how Indonesia perceived oneself internally, and externally.

In one newspaper article, the [then] President made some comments that illustrate how this global phenomena affecting national action and values. The article was a journalist report about Indonesia receiving the top literacy award given by the UNESCO to acknowledge the success of educational program in regard to women empowerment in Indonesia. The program is successful for making around 3 million Indonesian women literate.

This achievement proves that Indonesia's literacy program has successfully enhanced educa-tional quality and eradicated illiteracy through entrepre-neurship, reading, culture and training that reached 3 million women ("President Attributes UNESCO Award to Women Empowerment ", 2012).

Despite of the title stating President attributes UNESCO award to women empowerment, the emphasis of the President's statement was more on celebrating the successful program that was able to increase 'educational quality' and 'eradicated illiteracy'. At the same time, UNESCO is introducing itself as an organization that focuses 'in particular, on two global priorities; Africa and gender equality'(UNESCO, my italics). Therefore, the UNESCO was acknowledging Indonesia's achievement in promoting gender equality through literacy program that empowers women, but the government was more interested in the 'quality'. Although it is not necessarily contradict to the national policy, but it also does not mention the principle of equality as explicitly stated in the foundation principles of national policy of education.
A national education system should ensure equal opportunity, improve- ment of quality and relevance and efficiency in management to meet various challenges of local, national, and global lives; therefore it requires well-planned, well-directed, and sustainable education reform.

The President also mention about 'entrepreneurship' and 'training' in association to education. The tone in the President's statement is not uncommon discourse. Starr (1991) suggests the discourse of the South Australian Education Department policy 'is full of talk about vocational training/industrial links, the dominance of mathematics/ science/tech-nology in creating the 'clever country' and the need for a more literate populace' (Starr, 1991, p. 4). Here we can see the similarities of discourses used in different countries as one impact of how globalization affects our way of perceiving ourselves.

Although it is a common discourse, Hursh and Henderson (2011) warned the danger of focusing too much on mathematics and literacy when we need people to respond to more complex and interdisciplinary query about the best way 
of living in this planet. The emphasis of education now is a 'narrow skill approach' that focuses on how to do well on standardized exams, while what we really need is for students to raise question and be responsive to environmental and social problems that we have (Hursh \& Henderson, 2011).

Another interesting quote from the article is President's statement that 'This achievement means that UNESCO recognized that Indonesia was ready to compete globally' ("President Attributes UNESCO Award to Women Empowerment ", 2012). Global competi-tion is a repeated theme in every aspect of our lives now. It is the main concern raised in this paper that the global movement where Indonesia is engaged in had forced Indonesia to adopt neoliberalism perspective and forgetting its true national ideology.

Indonesia's national identity or ideology is reflected in Pancasila or the Five Principles. The Five Principles are (1) belief in one God; (2) just and civilized humanity; (3) Indonesian unity; (4) democracy under the wise guidance of representative consultations, and (5) social justice for all the peoples of Indonesia ("Pancasila ", 2012). It is therefore reasonable to expect social justice should be the main goal of act of Indonesia's national policies. However, particularly in practice, it is not seem to be the case anymore.

The statement marked by the President would have very different meaning if only he talked about promoting education for all or equality in education, which ideally focus on how to provide education accessible for all Indonesian citizens. The same time that Indonesia celebrating $93 \%$ of its literacy rate ("President Attributes UNESCO Award to Women Empo-werment ", 2012), we have overlooked the $7 \%$ group of our population that is still illiterate. Although the rate was considered 'competitive' in comparison toward Malaysia and Singapore, each with 93\% and $95 \%$ literacy rate respectively ("President Attributes UNESCO Award to Women Empowerment ", 2012), but the large population of Indonesia means that $7 \%$ is $17,500,000$ (seventeen million and five hundred thousand) people, which is almost as much as the entire population of Australia. The global perception, the national rank against the world, and the statistics, are often used to illustrate the condition of the nation, which unfortunately increasing the risk to marginalize a particular group. Like Gindin (2002) said, 'The economy is doing great, but the people in it aren't' (p.7).

Obviously, we do need improvement in educational quality or increased of economic growth; however, the concern lies in whether chasing quality or economic growth has to sacrifice equality. Is it really 'one or the other' condition? Is it a condition that we have to take in order to increase our rank in the world to exclude social justice out of the discourse? Gindin (2002) suggests that the danger of globalization lies when we shrink our ideal of social justice to fit in globalization framework, instead of thinking how globalization might work in our idea of social justice. The danger lies when we move blindly toward global competition just because that is what everybody else is doing and merely repeating what is being said just because it is repeated so many times without recognizing who we are.

Hursh and Henderson (2011) suggests that despite of the 'devastating consequences for economic equality, the environment, and education', neoliberalism remains global and dominant due to its domination in 'the discourse and logic regarding economic, political, and environmental decision-making' and have mostly 'succeeded in marginalizing alternative conceptions' (Hursh \& Henderson, 2011, pp. 171-172). In other words, if you say 
something over and over again, people will end up believing what you are saying.

Furthermore, Hursh and Henderson (2011) suggests that contesting neoliberalism should be conducted in three levels,' the discursive, the political, and the pedagogical' (p.182). Therefore, putting social justice back into the discourse, whether if it is a national policy or just a discussion about pedestrian's rights is an important step in challenging the dominant discourse. Offering a different way of thinking and taking perspective can be an effective way of raising awareness about what is going on. Awareness is always a good start of solving a problem.

The level of political could take example of Porto Alegre. The approach that Porto Alegre took is known as 'globalization from below' particularly in governance and education (Gandin, 2011; Gindin, 2002). The main idea of the approach is to acknowledge the popular sector and the values or 'wisdom' that they have. Porto Alegre recognizes the uniqueness of locality and community and allows them to be involved in, for example, construction of the school, which then increase their sense of belonging. In align to that Starr (1991) suggests that it is important to keep the following question in mind'who are we thinking when we formulate a policy or social justice?' Likewise, Conell (2003) suggests that we should look at all policies from the position of the most disadvantaged. Therefore, in education for example, we should think who would be most likely to be the disadvantaged group when international standard schools are being implemented and what we can do to overcome that.

Finally, in pedagogy, educators must first be aware of issues of social justice to be able to encourage and provoke students to think of the privilege that they may or may not have, and where is their position in social justice. Hursh and Henderson (2011) suggests that education needs to promote 'critical analysis and active participation in creating an alternative to neoliberalism' (p.183).

\section{Conclusion}

To be concluded, although the position toward globalization as described in this paper is quite sceptical, the most important thing is not how to reject globalization but rather to be able to criticise and recognize its impact to our values and how we perceived ourselves in relation to the world to continuously rethink of where social justice lies and how it should be reflected in national policies. Only by doing so, Indonesia can be part of globalization without losing its national identity that speaks for all people of Indonesia.

\section{References}

Bloom, D. E. (2006). Education in Globalized World. World Economics, 7(4).

Conell, R. W. (2003). Working class families and the new secondary education. Australian journal of education, 47(3), 235-250.

Gandin, L. A. (2011). Porto Alegre as a counter-hegemonic global city: building globalization from below in governance and education. Discourse: Studies in the cultural politics of education 32(2), 235252.

Gindin, S. (2002). Social Justice and Globalization: Are they Compatible? Monthly review: An independent socialist magazine, 54(02 (June)). Retrieved from 
http://monthlyreview.org/2002/06/0 1/social-justice-and-globalizationare-they-compatible website:

Globalization, Growth, and Poverty: Building an inclusive world economy. (2002). Oxford: The World Bank.

Human Development Report. (2011). New York: United Nations Development Programme (UNDP).

Hursh, D. W., \& Henderson, J. A. (2011). Contesting global neoliberalism and creating alternative futures. Discourse: Studies in the cultural politics of education, 32(2), 171185.

ILO Declaration on Social Justice for a Fair Globalization. (2008). Geneva: International Labour Organization.

Kemdikbud (2012). Dokumen Kurikulum 2013.

Kustulasari, A. (2009). The International Standard School Project in Indonesia: a Policy Document Analysis. (Master of Arts Master Thesis), The Ohio State University, Ohio.
Pancasila (2012) Encyclopedia Britannica: facts matter: Encyclopaedia Britannica, Inc.

President Attributes UNESCO Award to Women Empowerment (2012, August 29, 2012). Jakarta Post. Retrieved from http://www.thejakartapost.com/new s/2012/08/24/president-attributesunesco-literacy-award-womenempowerment.html

Sakhiyya, Z. (2011). Interrogating identity: the international standard school in Indonesia. Pedagogy, Culture, \& Society, 19(3), 345-365.

Starr, K. (1991). Justice for whom? - A critique of the social justice strategy of the South Australian Education Department. South Australian Educational Leader, 2(5).

UNESCO. Introducing UNESCO: what we are. Retrieved August 29, 2012, 2012 , from http://www.unesco.org/new/en/unes co/about-us/who-weare/introducing-unesco/ 